\title{
Stratejik Performans Yönetiminde Finansal Performans Değerlemesi: BiSTT Otomotiv Sektöründe Bir Uygulama
}

\author{
Financial Performance Evaluation in Strategic Performance Management: An \\ Application in The Automotive Sector of BIST
}

Yusuf ESMER*

Faruk $D A Y I^{* *}$

\section{$\ddot{O} Z$}

Otomotiv sektörü, ihracat, istihdam, kredi yönetimi gibi çeşitli faktörler açısından ekonominin gelişmesi ve kalkınmasında önemli bir tetikleyicidir. Katma değeri yüksek bir sektör olup Türkiye’nin ihracatında önemli bir paya sahiptir. Firmaların stratejik performans yönetiminde, üretim, pazarlama, finans gibi birçok alanda kararlar alınmakta; firmaların performanslarının değerlendirilmesinde finansal performansları ön plana çıkmaktadır. Bu nedenle ekonomiye katkısı oldukça yüksek olan otomotiv sektörünün finansal performansının değerlendirilmesi gerekmektedir. Borsa Ístanbul'da (BIST) işlem gören otomotiv firmalarının 2010-2017 dönemine ait 8 ylllı verilerinden hesaplanan oranların kullanıldı̆̆ bu çalışmada, açıklayıcı faktör analizi ve hiyerarşik kümeleme analizi yapılarak firmaların finansal performanslar değerlendirilmiştir. Çalışma sermayesi devir hızı, net kâr marjı, cari oran, kısa vadeli yabancı kaynaklar/toplam pasif ve toplam yabancı kaynaklar/toplam pasif oranlarının finansal performans değerlemesinde önemli etkiye sahip oldukları tespit edilmiştir. Kümeleme analizi sonucuna göre Ford ile Otokar firmaları birbirlerine en yakın; Karsan ile Federal Mogul firmaları birbirlerine en uzak performansı gösterdikleri bulgulanmıştır.

ANAHTAR KELIMELER

Stratejik Performans Yönetimi, Finansal Performans, Oran Analizi, Faktör Analizi, Hiyerarşik Kümeleme Analizi, Otomotiv Sektörü

ABSTRACT

The automotive sector is an important sector that development of the economy in terms of diversity factors such as export, employment and credit management. It is a sector with high added value and has a significant share in our Turkey exports. In strategic performance management of companies, decisions are taken in many areas such as production, marketing and finance; The financial performance of the companies in the performance of the company stands out. Therefore, the financial performance of the automotive sector, which has a high contribution to the economy, needs to be evaluated. In this study, the ratios calculated from the 8-year data of the automotive companies traded in Borsa Istanbul (BIST) for the period of 2010-2017 were used. In this study, explanatory factor analysis and hierarchical clustering analysis were performed and financial performances of firms have been evaluated. It has been determined that working capital turnover, net profit margin, current ratio, short term foreign sources / total liabilities and total foreign resources / total liabilities ratios have a significant effect on the financial performance evaluation. As a result of clustering analysis, while Ford and Otokar companies show the same performance to each other, Karsan and Federal Mogul companies show the most distant performance.

\section{KEYWORDS}

Strategic Performance Management, Financial Performance, Ratio Analysis, Factor Analysis, Hierarchical Cluster Analysis, Automotive Sector

\begin{tabular}{|c|c|c|}
\hline \multicolumn{2}{|c|}{ Makale Geliş Tarihi / Submission Date } & \multicolumn{1}{c|}{$\begin{array}{c}\text { Makale Kabul Tarihi / Date of Acceptance } \\
12.11 .2019\end{array}$} \\
\hline \multirow{3}{*}{ Atıf } & \multicolumn{2}{|c|}{$\begin{array}{l}\text { Esmer, Y. ve Dayı, F. (2019). Stratejik Performans Yönetiminde Finansal Performans Değerlemesi: BİST Otomotiv } \\
\text { Sektöründe Bir Uygulama. Selçuk Üniversitesi Sosyal Bilimler Meslek Yüksekokulu Dergisi, 22 (2), 628-645. }\end{array}$} \\
\hline
\end{tabular}

\footnotetext{
* Dr. Öğr. Üyesi, Bayburt Üniversitesi, Uygulamalı Bilimler Fakültesi, yesmer@ bayburt.edu.tr, ORCID: 0000-0003-3691-1730

${ }^{* *}$ Dr. Öğr. Üyesi, Kastamonu Üniversitesi, İktisadi ve İdari Bilimler Fakültesi, fdayi@kastamonu.edu.tr, ORCID: 0000-0003-0903-1500
} 


\section{GİRIŞ}

Günümüz otomotiv endüstrisi otomotiv teknolojisinin gelişmesiyle birlikte adeta altın çağını yaşamaktadır. Otomotiv firmalarının küçük, ergonomik, akıllı ve elektrikli otomobil üretme stratejileri piyasada olumlu karşılanmış otomotiv sektörünün pazarı büyümüştür (Kushwaha ve Sharma, 2016: 116). Otomotiv endüstrisi, ülke ekonomisinin önde gelen ve diğer sektörleri tetikleyici etki yapan ve hızla gelişen ve büyüyen sektörlerinden biri olarak görülmektedir (Yurdakul ve İç, 2003: 2; Bayraktar, 2004: 9). Otomotiv sektörü dünyada olduğu gibi Türkiye için de ekonominin önemli dinamiklerinden biri olmuş, toplam ihracat içindeki payı her geçen yıl artmıştır. Otomotiv sektörü, makinesinden, tornasına, derisinden, ahşabına kadar birçok sektörden ürün ve hizmet aldığından ekonomiye katkısı oldukça yüksektir. Katma değeri yüksek olduğundan, ekonomik büyüme ve kalkınma üzerinde büyük bir çarpan etkisine sahiptir. Otomotiv sektörünün bir dolarlık katma değer artışına karşılık üç dolarlık katma değer artışı sağladığı tahmin edilmekte ve günümüzde doğrudan ve dolaylı olarak çok sayıda kişiye de istihdam sağlamaktadır (Ildırar ve Kıral, 2018: 95). Bu bağlamda yatırımcılar, işletme sahipleri ve kredi kuruluşları sektördeki işletmelerin gelecekte sağlayacağı başarı ile getireceği kazancı doğru tahmin etmek istemektedir (Özşahin ve Yüregir, 2012: 156). Bu nedenle sektördeki firmaların finansal performansları değerlendirilerek, finansal başarıya etki eden faktörlerin saptanması Türkiye ekonomisine önemli katkılar sağlayacağı düşünülmektedir.

Otomotiv sektörünün ülkemiz için en büyük avantajı ülkemizdeki otomobil firmalarının Avrupa, OrtaDoğu gibi coğrafyalara kolayca ihracat yapabilmesidir. Sektörün en önemli dezavantajı ise yerli otomobil markasının olmayışıdır. Sektörde yabancı sermayenin hâkim olması, yeni yatırımlar için yabancı ortaklıkların kurulmasını gerektirmektedir. Ülkemizde yerli otomobil markası üretimi için çalışmalara devam edilmektedir. Benzin ve dizel gibi fosil yakıtlardan çok yenilenebilir enerji kaynaklarıyla çalışan otomobillerin üretilmesi otomotiv sektörünün geleceğinde büyük bir rekabeti de beraberinde getireceği tahmin edilmektedir. Fosil yakıtlı otomobiller, otomotiv sektörünün geleceği için önemli bir tehdit oluşturacağı düşünülmektedir (Kushwaha ve Sharma, 2016: 116). Fosil yakıtları tüketen otomobilin üretim maliyeti yeni nesil otomobillere göre daha düşük olsa da çevreyi kirletmenin maliyeti daha yüksektir (Gonenc ve Scholtens, 2017: 307-308). Otomobil firmalarının yeşil üretim yapabilmeleri için yeşil finans ve pazarlama stratejilerinin birlikte geliştirilmesi gerekir (Polonsky ve Rosenberger, 2001: 21). Çünkü yeni nesil otomobillerin üretilmesi için yüksek tutarlı ARGE çalışmaları gerekmektedir. Yüksek maliyetli yatırımlar için sermayenin rasyonel ve optimal kullanılacağı yatırım projeleri hazırlanmalıdır. Yatırım projelerinde başarı düzeyinin yükselebilmesi için iyi bir finansal planlama gerekmektedir. İlk olarak otomotiv işletmelerinin başarı düzeyleri tespit edilmelidir. Finansal performanstaki başarı ölçütlerinin doğru tespit edilmesi, mali tabloların doğru okunması ve yorumlanması ve etkin bir çalışma sermayesi yönetiminin finansal performansı olumlu yönde etkilemesi beklenmektedir. Firmanın finansal başarısı, gelecekte muhtemel yapılması düşünülen yatırımları da doğrudan etkilemektedir. Sermaye bütçelemesi sürecinde, yönetici mevcut kaynaklardan en iyi faydayı sağlayacak örgüt yapısını oluşturmaktadır. Sürdürülebilir finansal yönetim, firmanın gelecekte planladığı yatırımlar için gerekli fonların önceden uygun maliyet ve koşullarda teminini gerektirmektedir. $\mathrm{Bu}$ nedenle finansal yönetim performansında başarıyı sağlamak için etkin bir finansal yönetim becerisine sahip bir yönetim ekibine ihtiyaç duyulmaktadır. Ancak finansal performansın etkin ve stratejik yönetilebilmesi için finansal performans yönetimine etki eden faktörlerin tespit edilerek sinıflandırılması gerekmektedir.

$\mathrm{Bu}$ çalışmada işletmelerde stratejik performans yönetiminde finansal performans yönetimine etki eden finansal faktörlerin sınıflandırılması amaçlanmaktadır. Finansal performans göstergesi olarak finansal tablo verilerinden hesaplanan oranlar kullanılmıştır. Bu amaç doğrultusunda Türkiye' de faaliyet gösteren ve Borsa İstanbul'da işlem gören 11 otomotiv firmasına ait 2010-2017 y1lları arası finansal veriler, oran analizi, Açıklayıcı Faktör Analizi ve Hiyerarşik Kümeleme Analizi entegrasyonu ile analiz edilmiştir. Böylece faktör analizi ile finansal performansa etki eden faktör yükleri hesaplanmış ve kümeleme analizi ile firmaların performansları sınıflandırılarak birbirleriyle karşılaştırılmıştır.

\section{LITERATÜR}

Bu bölümün ilk kısmında Türkiye ve dünyadaki otomotiv sektörünün finansal durumu hakkında bilgi verilmiştir. İkinci kısımda stratejik performans yönetimi açıklanmıştır. Üçüncü kısımda finansal performans yönetimi incelenmiştir. Dördüncü kısımda finansal performans değerlemesi ve oran analizine yer verilmiştir.

\subsection{Türkiye ve Dünya'da Otomotiv Sektörünün Finansal Durumu}

Otomotiv sektörü diğer sektörleri etkileyen, doğrudan tüketilen ve tüketicilerin ihtiyaçlarına göre üretim yapılan bir sektördür. Otomobiller günlük yaşamımızın vazgeçilmez bir parçası olmuştur. Otomobil insanların hayatında en çok kullanılan ve vakit geçirilen araçlardan biridir. Park sorunu ve kaza oranı gibi önemli sorunlar 
olsa da otomobil, insanların hayatından vazgeçemeyecekleri önemli bir eşya olarak görülmektedir (KPMG, 2018: 3). Tüketicilerin otomobil satın alım kararlarını etkileyen faktörler ile ilgili olarak yapılan bir araştırmada sırasıyla otomobilin fiyatı, servis bakım hizmetleri ve çevreden elde edilen bilgilerin etkili olduğu tespit edilmiştir (Cop ve Gümüş, 2009: 192).

Otomotiv sektöründe gelişen teknolojiye uyum sağlayabilmek için çeşitli yatırımlar yapılmaktadır. Teknolojide yaşanan gelişmeler firmalar için rekabet avantajı sağlayacağı gibi önemli bir maliyet unsuru da olabilmektedir. Otomotiv sektöründeki yaşanan gelişmeler ARGE yatırımlarının tutarını artırmaktadır. Günümüzde gündemde olan Endüstri 4.0 uygulamasını ilk uygulayanlardan biri de otomotiv sektörüdür. Dolayısıyla bilişim, bilgisayar ve yazılım endüstrilerinde yaşanan gelişmeler otomotiv sektörünü de doğrudan etkilemektedir. Bu nedenle otomotiv sektöründe rekabet edebilmek, sadece müşterilerin isteklerini yetine getirmekle değil aynı zamanda firmanın performans yönetiminde topyekûn etkinliğin ve verimliliğin sağlanması ile mümkündür.

Dünya genelinde otomobil üretimi 1990-1999 yılları arasında 38,2 milyon; 2000-2013 yılları arasında 63,74 milyon, 2014 y1lında 75,61 milyon, 2015 y1lında 76,77 milyon, 2016 y1lında 81,35 milyon adet gerçekleşmiştir (KPMG, 2018: 4). 2008 yılında yaşanan kriz otomotiv sektörünü de olumsuz etkilemiştir. Küresel finansal krizin olumsuz etkileri başta $\mathrm{ABD}$ olmak üzere birçok ülkedeki otomotiv sektörünü olumsuz etkilemiş, 2008-2010 döneminde Suzuki, Hyundai ve Honda gibi küresel otomotiv firmalarının üretim hacmi azalmış ve satış gelirleri düşmüştür (Afzal vd., 2013: 136). Krizin etkisinin azalmasıly dünya otomotiv sektörü toparlanmış ve yeni nesil ürünler geliştirilmeye başlanmıştır.

Türkiye'de 2017 yılında 82,47 milyon ve 2018 yılında 84,08 milyon otomobilin satılacağı tahmin edilmektedir. Türkiye' deki otomobil üretimi 2007 yılında yaklaşık 1,1 milyon adet iken, 2017 yılının ilk 11 ayında 1,54 milyona; ülkemizde üretilen ve ihracat yapılan otomobillerin sayısı 2007 yılında 820 bin iken, 2017 yılının ilk 11 ayında 1,21 milyona ulaşmıştır. Türkiye'de otomotiv sektörü ihracatının değeri Kasım 2017 tarihi itibariyle yaklaşı 26 milyar dolar düzeyinde olup ülkemizin toplam ihracatındaki payı \%18,3 civarındadır. Avrupa piyasası Türkiye için önemli bir konuma sahip olup toplam ihracatın \%77'lik kısmı Avrupa'ya yapılmıştır (KPMG, 2018: 4-11). Aynı başarı 2018 yılında da görülmektedir. Otomotiv sektöründe ihracat tutarı 2018 yılının ilk altı ayında bir önceki yılın aynı dönemine göre \%14,5 artarak 16 milyar 434 milyon dolara yükselmiş olup en fazla ihracat yapılan ülkeler ise sırasılla Almanya, Birleşik Krallık, İtalya, İspanya ve Fransa olmuştur. Otomotiv Distribütörleri Derneğinin 26 Temmuz 2018 tarihinde yaptığı basın açıklamasında, Avrupa otomotiv piyasasında 2018 yılının ilk altı ayı sonunda toplam üretim \%3 artarak, 10,02 milyon araca ulaşıldığı belirtilmiştir (ODD, 2018: 1-9). Dolayısıyla Avrupa bölgesinde olduğu üzere Türkiye'de de otomotiv sektörü hızla büyümekte ve gelişmektedir.

BİST'de işlem gören otomotiv sektöründe faaliyet gösteren firmaların 2010-2017 dönemi aktif toplamları ve satış gelirlerinin toplamları Tablo 1'de verilmiştir.

Tablo 1: Otomotiv Sektörünün 2010-2017 Dönemi Toplam Aktif ve Satış Gelirleri (TL)

\begin{tabular}{|c|c|c|}
\hline Yıllar & Aktif Toplamı & Satış Gelirleri \\
\hline 2010 & 10.552 .866 .572 & 15.833 .780 .981 \\
\hline 2011 & 13.129 .856 .434 & 20.526 .516 .016 \\
\hline 2012 & 13.640 .578 .280 & 19.216 .458 .433 \\
\hline 2013 & 15.932 .655 .652 & 22.034 .844 .963 \\
\hline 2014 & 18.444 .005 .847 & 22.478 .033 .666 \\
\hline 2015 & 23.978 .610 .729 & 31.128 .972 .042 \\
\hline 2016 & 27.226 .510 .507 & 36.655 .431 .322 \\
\hline 2017 & 33.619 .196 .329 & 47.665 .117 .932 \\
\hline
\end{tabular}

Kaynak: Firmaların 2010-2017 Dönemi Konsolide Finansal Tabloları

Otomotiv sektörünün toplam varlıkları 7 yıllık dönemde 10,552 milyon liradan, 33,619 milyon liraya yükselmiştir. Aynı dönemde sektörün satış gelirleri 15,833 milyon liradan, 47,665 milyon liraya yükselmiştir. Sektörde faaliyet gösteren firmaların varlıkları 7 yıllık dönemde \%218 artarken, satış gelirleri ise \%201 oranında artmıştır. $\mathrm{Bu}$ durum sektörde yapılan yatırımların satışlardan daha fazla oranda arttığını göstermektedir. Sektörün varlıklarının etkin kullanıldığı düşünülmektedir. Çünkü reel sermaye yatırımlarının geri dönüşleri uzun yıllar sürebilmektedir.

Türk otomotiv sektöründe faaliyet gösterip Borsa İstanbul'da işlem gören firmaların 2017 yılı itibariyle toplam aktiflerine göre sıralanış1 Tablo 2'de verilmiştir. 
Tablo 2: Otomotiv Sektöründeki Firmaların 2017 Yılı Sıralamaları

\begin{tabular}{|c|l|r|}
\hline Sıra & Firmanın İsmi ve Ticaret Unvanı & Toplam Aktif (TL) \\
\hline 1 & Tofaş Türk Otomobil Fabrikası A.Ş. & 13.875 .148 .000 \\
\hline 2 & Ford Otomotiv Sanayi A.Ş. & 12.021 .740 .000 \\
\hline 3 & Otokar Otomotiv ve Savunma Sanayi A.Ş. & 2.009 .587 .000 \\
\hline 4 & Karsan Otomotiv Sanayi ve Ticaret A.Ş. & 1.826 .045 .346 \\
\hline 5 & Anadolu Isuzu Otomotiv Sanayi ve Ticaret A.Ş. & 1.453 .483 .993 \\
\hline 6 & Persan Makine Parçaları Sanayi A.Ş. & 1.252 .952 .268 \\
\hline 7 & Katmerciler Araç Üstü Ekipman Sanayi ve Ticaret A.Ş. & 524.595 .729 \\
\hline 8 & Ege Endüstri ve Ticaret A.Ş & 432.646 .832 \\
\hline 9 & Bosch Fren Sistemleri Sanayi Ticaret A.Ş. & 94.465 .584 \\
\hline 10 & DiTAŞ Doğan Yedek Parça İmalat ve Teknik A.Ş. & 78.060 .574 \\
\hline 11 & Federal-Mogul İzmit Piston ve Pim Üretim Tesisleri A.Ş. & 50.471 .003 \\
\hline
\end{tabular}

Kaynak: Firmaların 2017 Dönemi Konsolide Finansal Tabloları

Borsa İstanbul'da işlem gören firmaların aktif toplamları 33,619 milyon liradır. Sektördeki en büyük iki firma sırasıyla \%41,27'lik pay ile Tofaş Türk Otomobil Fabrikası A.Ş. ve \%35,75'lik pay ile Ford Otomotiv Sanayi A.Ş.' dir. Toplam aktifi en düşük firma ise \% 0,15'lik pay ile Federal-Mogul İzmit Piston ve Pim Üretim Tesisleri A.Ş.'dir. Sektördeki en büyük iki firmanın toplam varlıkları sektörün \%77,02'lik kısmını oluşturmaktadır. Dolayısıyla iki firmanın finansal performansı, sektörün performansını doğrudan etkilemektedir.

Türk otomotiv sektöründe faaliyet gösterip Borsa İstanbul'da işlem gören firmaların 2017 yılı itibariyle satış gelirleri Tablo 3'de verilmiştir.

Tablo 3: Otomotiv Sektöründeki Firmaların 2017 Yılı Satış Gelirleri (TL)

\begin{tabular}{|c|l|r|}
\hline Sıra & Firmanın İsmi ve Ticaret Unvanı & Satış Gelirleri \\
\hline 1 & Ford Otomotiv Sanayi A.Ş. & 25.341 .290 .000 \\
\hline 2 & Tofaş Türk Otomobil Fabrikası A.Ş. & 17.467 .806 .000 \\
\hline 3 & Otokar Otomotiv ve Savunma Sanayi A.Ş. & 1.785 .272 .000 \\
\hline 4 & Anadolu Isuzu Otomotiv Sanayi ve Ticaret A.Ş. & 963.126 .462 \\
\hline 5 & Karsan Otomotiv Sanayi ve Ticaret A.Ş. & 953.186 .497 \\
\hline 6 & Ege Endüstri ve Ticaret A.Ş & 345.972 .148 \\
\hline 7 & Persan Makine Parçaları Sanayi A.Ş. & 311.941 .641 \\
\hline 8 & Katmerciler Araç Üstü Ekipman Sanayi ve Ticaret A.Ş. & 177.225 .811 \\
\hline 9 & Bosch Fren Sistemleri Sanayi Ticaret A.Ş. & 161.084 .307 \\
\hline 10 & DiTAŞ Doğan Yedek Parça İmalat ve Teknik A.Ş. & 87.223 .084 \\
\hline 11 & Federal-Mogul İzmit Piston ve Pim Üretim Tesisleri A.Ş. & 70.989 .982 \\
\hline
\end{tabular}

Borsa İstanbul'da işlem gören otomotiv firmalarının toplam satış gelirleri 57,665 milyon liradır. Aktif toplamı büyük olan üç şirketin satış gelirleri, sektördeki toplam satış gelirinin büyük bir kısmını oluşturmaktadır. Ancak aktif toplamına göre 4.sırada yer alan Karsan, satış gelirlerine göre 5.sırada; aktif toplamına göre 5.sırada yer alan Anadolu Isuzu, satış gelirlerine göre 4.sırada yer almaktadır.

\subsection{Stratejik Performans Yönetimi}

Stratejik performans yönetimiyle ilgili son zamanlarda yapılmış çalışmalar incelendiğinde, değerli, nadir, eşsiz ve yerine koyulamayan kaynakların etkin yönetilmesi, firmaların performansının artmasında etkili olduğu belirtilmektedir (Morgan, 2012: 103). Stratejik performans yönetiminde, firmaların dinamik piyasa koşullarında karşılaşacakları engelleri dikkate alarak mevcut kaynaklarını planlanması ve onların etkin yönetimi, performansı artırdığ 1 ifade edilmektedir (Teece vd, 1997: 509-511). Firmaların performans düzeyinin yükseltilmesinde bilgi, üretim ve işgücü yeteneğinin de önemli bir katkısının olduğu tespit edilmiştir 
(Helfat ve Raubitschek, 2000: 961). Lepak ve Snell (1999), firmaların performanslarında işgücünün önemli olduğunu, insan kaynağının etkin ve verimli yönetilmesi gerektiğini, işgücünün sermaye gibi değerli olduğunu; makroekonomik açıdan düşünüldügünde ise ekonomik kalkınma ve büyümede istidamın önemli olduğunu ifade etmektedir. Çünkü bir ülkenin büyümesi ve kalkınması nitelikli işgücünün üretim sürecine katılmasıyla artacağı düşünülmektedir.

Stratejik performans yönetimi, işletmenin tüm fonksiyonlarının birlikte yönetilmesini gerektirmektedir. Finansal performans, finansal kaynak yönetimi, pazarlama performans1 ve yeniden yatırım performans1 stratejik performans yönetiminde önemli performans kriterleri olarak değerlendirilmektedir (Morgan, 2012: 102-104). Organizasyon sürecindeki tüm faktörlerin birlikte verimli çalışması için gerekli alt yapı yatırımları yapılmalıdır. Kurumsal yönetimin her aşamasında inovatif işlemlerin olması otomotiv sektöründe faaliyet gösteren yerel firmaların rekabet düzeyinin artmasında etkili olduğu belirtilmiştir (Xi vd., 2009: 476-477). Firmanın stratejik amaçlarına ve finansal planlarına uygun işgücü planlaması yapılmalıdır. Çünkü çalışanların maaş ve ödemeleri, firmalar için önemli bir maliyet unsuru ve nakit çıkışıdır. Tutundurma çabaları, satış geliştirme ve müşteri ilişkileri yönetimi, stratejik yönetimde performansı doğrudan etkilemektedir. Dolayısıyla pazarlama faaliyetlerinde, fiziksel kaynaklardan optimum fayda sağlamak performansı artırmaktadır. İşletmelerin stratejik pazarlama yönetimi sürecinde firma için müşterilerin değerini artırmak işletmelerin performansını artıracağı gibi firmanın hissedarlar açısından değerini de artırmaktadır (Srivastava vd., 1999: 168). Özellikle otomobil firmalarında müşterilerle iyi bir iletişimin kurulması, firmanın satışlarının artmasında önemli bir etken olduğu ifade edilmektedir (Falát ve Holubčík, 2017: 148). Firmanın bilgi ve iletişim teknolojisi yatırımları, müşteriler, tedarikçiler, mağazalar ve satış acenteleri arasında iletişimi hızlandırmaktadır. Böylece bilgi akışı kısa sürede ve uygun maliyetle sağlanmaktadır.

\subsection{Finansal Performans Yönetimi}

İşletmelerin amaçlarından biri de kâr elde etmektir. Kâr edemeyen bir işletmenin hayatını devam ettirebilmesi ve diğer (mal ve hizmet üretmek, topluma hizmet, sosyal sorumluluk, ülke ekonomisine katkıda bulunmak vb.) amaçlarını gerçekleştirebilmesi pekte mümkün değildir. "Kâr elde etmek" finansal bir amaç olmakla birlikte "kâr" bir işletmenin performans göstergelerinden sadece biridir. Performans, bir işletmenin başarı durumunu ifade etmektedir. Performans, bir faaliyetin sonucunda ulaşılan noktayı nitel ve nicel olarak gösteren bir kavramdır. İşletmelerde performansın en önemli boyutlarından birisi de finansal performanstır (Küçüközkan, 2017: 1). Finansal performans, firmaların finansal tablo ve muhasebe bilgilerinden yararlanılarak, finansal ve operasyonel işlemlerin karakteristik özelliklerinin belirlenme sürecidir (Ramya ve S.Kavitha, 2017: 93). Örneğin bir firmanın belirli bir dönem sonunda elde ettiği kâr o firmanın finansal performans düzeyini değerlendirmek için kullanılabilecek bir göstergedir. Finansal performans, firmaların geçmiş finansal durumlarını değerlendirerek gelecekle ilgili yöneticilere veri sağlamaktadır. Aynı zamanda finansal performans firma yöneticilerinin başarısını gösteren önemli bir ölçüttür. Bu bağlamda finansal performansin etkin ve stratejik yönetilmesi gerekmektedir.

Nakit, alacak ve stok yönetimi, firmanın yatırım kararları ve finanslama politikaları finansal performans üzerinde doğrudan etkilidir (Morgan, 2012: 104-106). Finansal performans yönetimi bir firmanın temel finansal, operasyonel ve pazarlama faaliyetlerinin değerlendirilmesi sürecidir (Kushwaha ve Sharma, 2016: 116). Finansal performans yönetimi, bir firmanın finansal sonuçları bir örgütte yönetip izlediği yolları ifade etmektedir. Finansal performans yönetiminin amacı, fiili sonuçları bütçelerle ve tahminlerle karşılaştırmak ve buna göre ayarlamalar yaparak, firmaların finansal hedeflerine ulaşmak için daha donanımlı olmalarını sağlamaktır. Ventana Araştırma Kurumu, finansal performans yönetimini, "İşletmelerin temel performans göstergelerini tanımlamak, stratejik planlar ve tahminler oluşturmak, performans raporlarını ele almak ve finans operasyonel verimliliğini artırmak ve şirket çapında yürütmek" gibi özel bir yetenek seti olarak tanımlamaktadır (Wolters Kluwer/CCH Tagetik, 2018: 1). Finansal performans yönetimi, işletmelerin değişen finansal önceliklerine odaklanmalarını sağlamakta, örgütsel verileri ve süreçleri bütünleştirerek geleneksel finans süreçlerini verimli hale getirmekte ve finansal mükemmelliğe ulaşmak üzere işletme yöneticilerine iş stratejilerini daha iyi belirleme becerisi kazandırarak stratejik bakış açısı kazandırmaktadır (SAP Business Objects, 2009: 3). Finansal performans yönetimi, işletmelerde kalitenin ve verimliliğin artmasına katkıda bulunmaktadır (Küçüközkan, 2017: 1). Etkin bir finansal performans yönetimi kurumsal yönetim başarısına da etkilemektedir. Kurumsal yönetim ilkelerini benimseyen ve kurumsal yönetim endeksinde yer alan işletmelerin varlıklarını sürdürebilmeleri için finansal performanslarının en etkin şekilde analiz edilmesi ve yönetilmesi gerekmektedir (Ege vd., 2013: 101). Dolayısıyla finansal performans ve finansal durumun analiz edilerek rakiplerle kıyaslanması işletmelerin stratejik yönetim sürecinde içinde bulundukları durumu görebilmeleri açısından yapmaları gereken önemli analizler arasında yer almaktadır. 


\subsection{Finansal Performans Değerlemesi: Oran Analizi}

Finansal tablolar analiz yöntemlerinden biri olan rasyo analizi ilk kez 19.yüzyılda sanayi devriminin yaşandığı dönemde Amerika'da uygulandığı görülmektedir. Dünya ekonomisinde yaşanan krizler, değişimler, savaşlar, küreselleşme ve firmaların finansal durumlarında yaşanan değişiklikler, firmaların finansal analizlerinin yapılmasını ve finansal durumlarının değerlendirilmesini gerektirmiştir (Ulusoy, 2011: 9088). 2000'li yıllarda finansal tabloların analizinde önemli bir yöntem olan oran analizi, borsada işlem gören firmaların hisse senetlerinin değerlemesinde de sıkça kullanılmaktadır (Wang ve Lee, 2008: 1087). Günümüzde yatırımcılar ve firma yönetimleri finansal performans değerlemesinde oran analizi yönteminden yararlandıkları bilinmektedir.

Oran analizi ile finansal sıkıntı diğer bir ifadeyle finansal başarısızlık riskiyle karşılaşacak muhtemel firmalar önceden tespit edilip gerekli önlemler alınabileceği ifade edilmektedir. Dolayısıyla firmaların ön kontrol mekanizması olarak finansal durumu ölçecek oranların tespiti firmaların denetimini kolaylaştırabilecektir (Chen ve Shimerda, 1981: 51). Günümüzde daha çok bankacılık sektöründe örneği görülmektedir. Basel kriterleri olarak ifade edilen ve Bankacılık Düzenleme ve Denetleme Kurumunun (BDDK) belirlediği çeşitli oranlar ve standart değerlerin altına düşen firmalar takibe alınmaktadır. Endüstri firmaları için de buna benzer uygulamaların yapılmasıyla firmaların finansal durumlarının güçlenebileceği düşünülmektedir.

Oran analizinde firmaların performanslarını karşılaştırırken literatürde yer alan standart değerler esas alınabileceği gibi sektörde faaliyet gösteren firmaların hesaplanmış sektörde referans alınabilecek değerler belirlenebilir. Firmaların performansının değerlendirilmesinde sadece oranlar yeterli gelmeyip, firmanın büyüklüğü, ölçeği, faaliyet gösterdiği endüstri olmak üzere birçok faktörün değerlendirilmesi gerekmektedir (Lev ve Sunder, 1979: 187).

Oran analizi firmanın finansal durumunu ve performansını değerlendirmek için yapılmaktadır. Oran analizi rasyo analizi olarak da ifade edilmektedir. Oran analizi, firmanın finansal durum tablosu ve gelir tablosu verilerinden yararlanılarak yapılmaktadır (Dayı, 2013: 95). Oran analizi, finansal tablolarda ilişkili olan çeşitli hesapların birbirine oranlanması ile yapılır (Çabuk ve Lazol, 2016: 198). Oran analizi altı oran grubundaki çeşitli oranlardan oluşmaktadır (Okka, 2015: 125). Literatürde genellikle likidite, mali yapı, kârlılık, verimlilik açısından firmaların performansının ölçülmesinde tercih edildiği görülmektedir (Ulusoy, 2008: 228). Firmanın likidite düzeyini ölçmek için likidite; mali durumunu incelemek için mali yapı; faaliyetlerin verimliliğini değerlendirmek için faaliyet oranları ve firmanın kârlılık durumunu değerlendirmek için kârlılık oranları olmak üzere orana analizi dört grupta toplanmaktadır (Akdoğan ve Tenker, 2007: 643). Ayrıca borsada işlem gören firmaların finansal durumlarını değerlendirmek içinde de borsa performans oranları kullanılmaktadır.

\section{LITERATÜR TARAMASI}

Literatürde yapılmış çalışmalar incelendiğinde otomotiv sektörüne yönelik "finansal performans değerlemesi" ve "oran analizi" ile ilgili çalışmalar yer almaktadır. Bu nedenle literatür taramasında otomotiv firmalarının performans analizi veya finansal performans yönetimiyle ilgili benzer çalışmalara yer verilmiştir. $\mathrm{Bu}$ çalışmalarda otomotiv firmalarının finansal performansları analiz edilirken farklı analiz yöntemlerinin kullanıldığı tespit edilmiştir. Literatürde yapılmış ulusal ve uluslararası çalışmaların yöntemleri, analizi ve sonuçları Tablo 4` de verilmiştir. 
Tablo 4: Literatür Taraması

\begin{tabular}{|c|c|c|}
\hline Araştırmacı & Yöntem & Çalışmanın İçeriği ve Sonuçları \\
\hline $\begin{array}{l}\text { Ramya ve Kavitha } \\
\text { (2017) }\end{array}$ & Oran Analizi & $\begin{array}{l}\text { Maruthi Suzuki firmasının 2010-2015 dönemine ait bilanço ve } \\
\text { gelir tablosu verilerinden yararlanılarak karlılık ve faaliyet hızı } \\
\text { oranları hesaplanmış, firmanın analiz sonuçları } \\
\text { değerlendirildiğinde söz konusu dönemde iyi bir finansal } \\
\text { performans sergilediği ifade edilmiştir. }\end{array}$ \\
\hline Gowda ve V (2017) & $\begin{array}{l}\text { Oran Analizi, } T \\
\text { Testi ve Kısmı } \\
\text { Korelasyon Analizi }\end{array}$ & $\begin{array}{l}\text { Hindistan'daki en büyük } 9 \text { firmanın } 2012-2016 \text { dönemi } \\
\text { verilerinden hesaplanan } 7 \text { oran ile finansal performanslarının } \\
\text { incelendiği çalışmada Likidite ve Cari oranın firmaların finansal } \\
\text { performansları üzerinde etkili olduğu görülmektedir. }\end{array}$ \\
\hline $\begin{array}{lll}\text { Yanık } & \text { ve } & \text { Eren } \\
(2017) & & \end{array}$ & $\begin{array}{l}\text { Oran Analizi, AHC, } \\
\text { TOPSIS, ELECTRE } \\
\text { ve VIKOR }\end{array}$ & $\begin{array}{l}\text { BIST'de işlem gören } 11 \text { otomotiv firmasının } 2010-2015 \text { dönemi } \\
\text { finansal tablolarından hesaplanan } 9 \text { oran kullanılarak finansal } \\
\text { performansları çeşitli yöntemlerle değerlendirilmiştir. Analiz } \\
\text { sonuçlarında net kar/ özkaynaklar oranının finansal performans } \\
\text { değerlemesinde önemli bir gösterge olduğu tespit edilmiştir. } \\
\text { Yöntemler farklı olsa da analiz sonuçları birbirine yakın } \\
\text { sıralamalar vermektedir. }\end{array}$ \\
\hline $\begin{array}{l}\text { Mathur ve Agarwal } \\
\text { (2016) }\end{array}$ & Ializi & $\begin{array}{l}\text { Hindistan'da faaliyet gösteren Maruthi Suziki ve Tata Motors } \\
\text { firmalarının 2012-2014 dönemi finansal tablo verilerinden } \\
\text { hesaplanan } 5 \text { rasyo ile yapılan analiz sonucunda Maruthi Suziki } \\
\text { firmasının Tata Motors firmasından daha iyi bir finansal } \\
\text { performans sergilediği tespit edilmiştir. }\end{array}$ \\
\hline $\begin{array}{l}\text { Arumugam vd. } \\
\text { (2016) }\end{array}$ & $\begin{array}{l}\text { Oran Analizi ve } \\
\text { Lineer Regresyon }\end{array}$ & $\begin{array}{l}\text { Otomotiv endüstrisinde faaliyet gösteren } 16 \text { firmanın } 2000 \text { - } \\
2014 \text { dönemine ait verilerinden elde edilen } 20 \text { oran ile analiz } \\
\text { yapılmıştır. Finansal performansın değerlendirilmesinde karlık } \\
\text { oranlarının istatistiksel olarak anlamlı olduğu tespit edilmiştir. }\end{array}$ \\
\hline $\begin{array}{ll}\text { Kushwaha } & \text { ve } \\
\text { Sharma (2016) } & \end{array}$ & $\begin{array}{l}\text { Nitel Araştırma } \\
\text { Yöntemi ve İçerik } \\
\text { Analizi }\end{array}$ & $\begin{array}{l}\text { Yaklaşık } 100 \text { makalenin incelendiği çalışmada otomobil } \\
\text { firmalarının performansının, doğayı koruma ve sürdürülebilir } \\
\text { kalkınma ile yakından ilişkili olduğu tespit edilmiştir. Firmaların } \\
\text { çevre kirliliği ve maliyet yönetiminde problem yaşadıkları; } \\
\text { performanslarını artırmak için emisyon gazı ve maliyet } \\
\text { baskısıyla karşılaştığı tespit edilmiştir. Çevre kirliliğini azaltmak } \\
\text { otomotiv firmalarının maliyetlerini artırdığını bunun da } \\
\text { firmanın finansal performansı üzerinde olumsuz etkiye neden } \\
\text { olduğu belirtilmektedir. }\end{array}$ \\
\hline $\begin{array}{l}\text { Ömürbek } \\
\text { (2016) }\end{array}$ & $\begin{array}{l}\text { Oran Analizi, } \\
\text { Entropi, MAUT ve } \\
\text { SAW Yöntemleri }\end{array}$ & $\begin{array}{l}\text { BIST'de işlem gören } 6 \text { otomotiv firmasının } 2014 \text { yılı verilerinden } \\
\text { elde edilen oranlar ile çeşitli finansal göstergeler, Entropi, } \\
\text { MAUT ve SAW yöntemleriyle finansal performansları } \\
\text { değerlendirilmiştir. Analiz sonuçlarında yöntemlerin } \\
\text { performans değerlendirmede önemli farklılık göstermedikleri } \\
\text { görülmektedir. }\end{array}$ \\
\hline $\begin{array}{l}\text { Tatlı ve Bayrak } \\
(2016)\end{array}$ & $\begin{array}{l}\text { Statik ve } \text { Dinamik } \\
\text { Veri Zarflama } \\
\text { Analizi (VZA) }\end{array}$ & $\begin{array}{l}\text { BiST' de işlem gören otomotiv üreticisi ve yan sanayisinde } \\
\text { faaliyet gösteren } 15 \text { firmanın 2010-2014 dönemi finansal } \\
\text { verileri kullanılarak VZA yapılmıştır. Analiz sonuçlarına göre } \\
\text { toplam } 4 \text { otomotiv işletmesinin etkinlik sınırı altında kaldığı, } 11 \\
\text { işletmenin ise tam etkinlik seviyesinde olduğu görülmüştür. } \\
\text { Ayrıca etkin olan işletmelerin ölçeğe göre sabit getiri özelliği; } \\
\text { etkinlik sınırı altında kalan işletmelerin ise ölçeğe göre artan } \\
\text { getiri özelliği taşıdığı tespit edilmiştir. }\end{array}$ \\
\hline
\end{tabular}




\begin{tabular}{|c|c|c|}
\hline $\begin{array}{l}\text { Jothi ve } \\
\text { Geethalakshmi } \\
(2016)\end{array}$ & Oran Analizi & $\begin{array}{l}\text { Hindistan otomotiv sektöründe } 4 \text { firmanın 2012-2016 dönemi } \\
\text { finansal tablolardan hesaplanan } 6 \text { oran ile finansal performans } \\
\text { değerlemesi yapılmıştır. Analiz sonucunda firmaların } \\
\text { performanslarının iyi olduğu; kârlılık oranlarının kısa ve uzun } \\
\text { dönem sermaye hareketleriyle ilişkili olduğu tespit edilmiştir. }\end{array}$ \\
\hline Szucs (2015) & $\begin{array}{l}\text { Oran Analizi, } \\
\text { Faktör Analizi ve } \\
\text { Kümeleme Analizi }\end{array}$ & $\begin{array}{l}\text { Macaristan otomotiv endüstrisinde faaliyet gösteren firmaların } \\
\text { faaliyet devir hızı oranları, mali yapı oranları ve kârlılık oranları } \\
\text { hesaplanmış, faktör ve kümeleme analizi yapılmıştır. Analiz } \\
\text { sonucunda oranların üç grupta kümelendiği, finansal } \\
\text { performansın değerlendirilmesinde önemli oldukları } \\
\text { vurgulanmıştır. }\end{array}$ \\
\hline $\begin{array}{l}\text { Jothi ve Kalaivani } \\
\text { (2015) }\end{array}$ & $\begin{array}{l}\text { Oran Analizi ve } \\
\text { Faktör Analizi }\end{array}$ & $\begin{array}{l}\text { Toyota ve Honda firmalarının } 2009-2014 \text { dönemleri mali } \\
\text { tablolarından toplanan verilerden yararlanılarak cari oran, } \\
\text { likidite oranı, nakit oran, toplam borç/özkaynaklar oranı, } \\
\text { özkaynaklar/pasif oranı, brüt kâr marjı ve net kâr marjı oranları } \\
\text { hesaplanmış; firmaların finansal durumlarının güven verdiği } \\
\text { belirtilmiştir. }\end{array}$ \\
\hline Pal (2015) & $\begin{array}{lr}\text { Oran } & \text { Analizi, } \\
\text { Faktör } & \text { Analizi ve } \\
\text { Çoklu } & \text { Regresyon } \\
\text { Analizi } & \end{array}$ & $\begin{array}{l}\text { Hindistan otomotiv sektöründe faaliyet gösteren } 9 \text { firmanın } \\
\text { 1999-2014 dönemine ait } 15 \text { yıllık verilerden } 33 \text { oran } \\
\text { hesaplanmış; faktör ve çoklu regresyon analizi ile firmaların } \\
\text { finansal performansı üzerin etkili olanlar tespit edilmiştir. } \\
\text { Çalışmanın sonucunda çalışma sermayesi/toplam aktif, stok } \\
\text { devir hızı ve nakit kar/temettü dağıtım oranının finansal } \\
\text { performans üzerinde etkili olabileceği tespit edilmiştir. }\end{array}$ \\
\hline Mesarić (2014) & Oran Analizi & $\begin{array}{l}\text { Hırvatistan'daki } 5 \text { büyük otomobil firmasının } 2007-2012 \\
\text { dönemi finansal tablolardan elde edilen } 8 \text { oranın kullanıldığı } \\
\text { çalışmada; firmaların performanslarının krizden dolayı düştüğü; } \\
\text { krizden sonra ise performanslarının arttığı ifade edilmiştir. }\end{array}$ \\
\hline Bulgurcu (2013) & $\begin{array}{l}\text { Oran Analizi ve } \\
\text { Entropi Ağırlıklı } \\
\text { TOPSIS Yöntemi }\end{array}$ & $\begin{array}{l}\text { IMKB' de işlem gören } 10 \text { otomotiv firmasının 2009-2012 } \\
\text { finansal tablolarından elde edilen } 10 \text { oran Entropi Ağırıklı } \\
\text { TOPSIS yönteminde kullanılmıştır. Analiz sonuçlarına göre, F-M } \\
\text { İzmit Piston işletmesi dört yıl boyunca en yüksek finansal } \\
\text { performans oranına sahipken, Parsan işletmesinin finansal } \\
\text { performans endeks değeri en düşük düzeydedir. Ford, Anadolu } \\
\text { Isuzu, Ege Sanayi, Ditaş Doğan gibi firmaların dört yıl boyunca } \\
\text { istikrarlı sonuçlar elde ettiği tespit edilmiştir. Ayrıca Entropi } \\
\text { Ağırlıklı TOPSıS olarak da tanımlanabilen bu tekniğin, objektif } \\
\text { değerlendirme sağlama açısından çok kriterli bir karar verme } \\
\text { yöntemi olduğu anlaşılmaktadır. }\end{array}$ \\
\hline $\begin{array}{l}\text { Dharmaraj ve } \\
\text { Kathirvel (2012) }\end{array}$ & $\begin{array}{l}\text { Oran Analizi ve t } \\
\text { Testi }\end{array}$ & $\begin{array}{l}\text { Hindistan otomotiv sektöründe faaliyet gösteren } 16 \text { firmanın } 13 \\
\text { yıllık verilerinden hesaplanan } 20 \text { oranın ortalama verileri } \\
\text { üzerinde yapılan t testinde likidite oranlarının çok değişmediği, } \\
\text { doğrudan yabancı yatırımlar ile firmaların finansal } \\
\text { performanslarının olumlu etkilendiği tespit edilmiştir. }\end{array}$ \\
\hline $\begin{array}{l}\text { Özşahin ve Yüregir } \\
\text { (2012) }\end{array}$ & $\begin{array}{l}\text { Oran Analizi, } \\
\text { Yapay Sinir Ağları } \\
\text { (YSA) ve Kendini } \\
\text { Örgütleyen } \\
\text { Haritalar (KÖH) }\end{array}$ & $\begin{array}{l}\text { 1998-2008 döneminde İMKB' de işlem gören } 6 \text { firmanın } \\
\text { finansal tablolarından hesaplanan } 24 \text { oran ve diğer veriler YSA } \\
\text { ve KÖH yöntemlerinde kullanılarak finansal durumları analiz } \\
\text { edilmiştir. Herhangi bir holdinge bağlı olmayan otomotiv } \\
\text { firmalarının finansal performans düzeyleri düşük seviyede } \\
\text { çıkmaktadır. Yönetimin merkezciliği otomotiv firmalarının } \\
\text { başarısını önemli ölçüde etkilemektedir. Ayrıca çalşan sayıs1 } \\
\text { fazla olan otomotiv işletmelerinin finansal performans düzeyi } \\
\text { yüksek olmaktadır. }\end{array}$ \\
\hline
\end{tabular}




\begin{tabular}{|c|c|c|}
\hline Bakırcı (2006) & $\begin{array}{l}\text { Veri Zarflama } \\
\text { Analizi (VZA) }\end{array}$ & $\begin{array}{l}\text { 1999-2004 yıllarında İMKB'de işlem gören } 13 \text { otomotiv } \\
\text { firmasının oran ve diğer finansal verileri VZA yönteminde } \\
\text { kullanılmıştır. Analizin önemli bir kıstası VZA yönteminin } \\
\text { "ölçeğe göre sabit getiri" ve "ölçeğe göre değişken getiri" } \\
\text { varsayımı altında yapılmasıdır. Analiz sonucunda küçük ölçekli } \\
\text { firmaların daha etkin oldukları ifade edilmiştir. Firmaların } \\
\text { toplam aktiflerinin \%21,54'ü, özkaynaklarının \%23,05'i ve } \\
\text { çalışanların sayısının \%17,73'lük kısmının azaltılması gerektiği } \\
\text { tespit edilmiştir. }\end{array}$ \\
\hline $\begin{array}{l}\text { Yurdakul ve íç } \\
\text { (2003) }\end{array}$ & $\begin{array}{l}\text { Oran Analizi ve } \\
\text { TOPSIS Yöntemi }\end{array}$ & $\begin{array}{l}\text { IMKB'de işlem gören } 5 \text { büyük otomotiv firmasının 1998-2001 } \\
\text { dönemi mali tablolarından hesaplanan oranlar, TOPSIS } \\
\text { yönteminde performans etkinlik analizine tabi tutulmuştur. } \\
1998-2000 \text { dönemi analiz sonuçlarında, firmaların hisse } \\
\text { senetlerinin değeri ile etkinlik skorları sıralamalarının tutarlı } \\
\text { olduğu ancak } 2001 \text { yılında farklııkların görüldüğü tespit } \\
\text { edilmiştir. }\end{array}$ \\
\hline
\end{tabular}

\section{VERİ SETİ VE YÖNTEM}

Çalışmanın bu bölümünde analizde kullanılan veri setleri, değişkenler ve örneklem ile çalışmanın analiz yöntemleri açıklanmaktadır.

\subsection{Veri Seti, Değişkenler ve Örneklem}

$\mathrm{Bu}$ çalışmada firmaların finansal performans yönetimine etki eden oranların sınıflandırılması ve finansal performanslarının karşılaştırılması amaçlanmaktadır. Bu kapsamda Borsa İstanbul'da işlem gören 11 otomotiv firmasının 2010-2017 dönemi finansal tablolarından (finansal durum tablosu ve gelir tablosu) elde edilen verilerden hesaplanan 17 oran kullanılarak analizler yapılmıştır. Verilerin frekans düzeyi yıllıktır. Analizde kullanılan değişkenler ve tanımları Tablo 5'de verilmiştir. 
Tablo 5: Analizde Kullanılan Değişkenler ve Tanımları

\begin{tabular}{|c|c|c|}
\hline Oran Adı & $\begin{array}{c}\text { Oran } \\
\text { Grubu }\end{array}$ & Tanım ve/veya Formül \\
\hline Cari Oran & Likidite & $\begin{array}{l}\text { Dönen varlıkların, kısa vadeli yabancı kaynakları karşılama } \\
\text { gücünü göstermektedir. } \\
\text { Oran=Dönen Varlıklar / KVYK }\end{array}$ \\
\hline Likidite Oranı (Asit Test Oranı) & Likidite & $\begin{array}{l}\text { Dönen varlıklardan stokların çıkarılmasıyla elde edilen } \\
\text { varlıkların, kısa vadeli borcu ödeme gücünü göstermektedir. } \\
\text { Oran = (Dönen Varlıklar - Stoklar)/ KVYK }\end{array}$ \\
\hline Nakit Oran & Likidite & $\begin{array}{l}\text { Firmanın nakit varlıklarının kısa vadeli borcu ödeyebilme } \\
\text { gücünü göstermektedir Oran = Nakit Varlıklar } / \text { KVYK }\end{array}$ \\
\hline $\begin{array}{l}\text { Toplam Borç/Toplam Pasif } \\
\text { Oranı }\end{array}$ & Mali Yapı & $\begin{array}{l}\text { Toplam kaynaklar içindeki toplam borç oranını } \\
\text { göstermektedir. }\end{array}$ \\
\hline $\begin{array}{l}\text { Kısa } \\
\text { Kaynaklar/Toplam Pasif Oranı }\end{array}$ & Mali Yapı & $\begin{array}{l}\text { Toplam kaynaklar içindeki kısa vadeli borç oranını } \\
\text { göstermektedir. }\end{array}$ \\
\hline $\begin{array}{l}\text { Devamlı Sermaye/Maddi } \\
\text { Duran Varlıklar }\end{array}$ & Mali Yapı & $\begin{array}{l}\text { Uzun vadeli yabancı kaynaklar ile özkaynaklar toplamının, } \\
\text { duran varlıkları kaç kez karşıladığını göstermektedir. }\end{array}$ \\
\hline Çalışma Sermayesi Devir Hızı & Faaliyet & $\begin{array}{l}\text { Çalışma sermayesinin (dönen varlıkların) bir yıl içinde kaç kez } \\
\text { döndüğünü göstermektedir. } \\
\text { Oran = Net Satışlar / Çalışma Sermayesi }\end{array}$ \\
\hline Alacak Devir HIzı (ADH) & Faaliyet & $\begin{array}{l}\text { bir yılda kaç kez tahsil edildiğini göstermektedir. } \\
\text { Satışlar / Ticari Alacaklar }\end{array}$ \\
\hline $\begin{array}{l}\text { Alacakların Ortalama Tahsil } \\
\text { Süresi }\end{array}$ & Faaliyet & $\begin{array}{l}\text { Alacakların kaç günde bir tahsil edildiğini göstermektedir. } \\
\text { Oran= } 360 \text { (365) / ADH }\end{array}$ \\
\hline Stok Devir HIZI (SDH) & Faaliyet & $\begin{array}{l}\text { Stokların bir yıl içinde kaç kez satıldığını göstermektedir. } \\
\text { Oran = Net Satışlar / Stok }\end{array}$ \\
\hline Stok De & Faaliyet & $\begin{array}{l}\text { Stokların kaç günde bir satıldı̆ıını göstermektedir. } \\
\text { Oran = } 360(365) / \text { SDH }\end{array}$ \\
\hline Aktif Devir Hızı & Faaliyet & $\begin{array}{l}\text { Satışlar karşısında toplam aktifin kaç kez döndüğünü } \\
\text { göstermektedir. } \\
\text { Oran = Net Satışlar / Toplam Aktif }\end{array}$ \\
\hline Brüt Kâr Marjı & Kârlılık & $\begin{array}{l}\text { Brüt kârın, net satışlara bölünmesiyle hesaplanmaktadır. } \\
\text { Oran = Brüt Kâr / Net Satışlar }\end{array}$ \\
\hline Esas Faaliyet Kârııık Oranı & Kârlılık & $\begin{array}{l}\text { Faaliyet kârının, net satışlara oranlanmasıdır. } \\
\text { Oran = Faaliyet Kârı / Net Satışlar }\end{array}$ \\
\hline Aktif Kârlılık Oranı & Kârlılık & $\begin{array}{l}\text { Net kârın toplam aktife bölünmesiyle hesaplanmaktadır. } \\
\text { Varlıkların verimli kullanılma durumunu göstermektedir. } \\
\text { Oran = Net Kâr / Toplam Aktif }\end{array}$ \\
\hline Özsermaye Kârlııı Oranı & Kârlılık & $\begin{array}{l}\text { Net kârın Özsermaye toplamına bölünmesiyle } \\
\text { hesaplanmaktadır. Özkaynakların verimli kullanılma } \\
\text { durumunu göstermektedir. } \\
\text { Oran = Net Kâr / Özkaynaklar }\end{array}$ \\
\hline Net Kâr Marjı & Kârlılık & $\begin{array}{l}\text { Net kârın, net satışlara bölünmesiyle hesaplanmaktadır. } \\
\text { Firmanın net kârlılığını göstermektedir. } \\
\text { Oran = Net Kâr / Net Satışlar }\end{array}$ \\
\hline
\end{tabular}

Borsa İstanbul'da işlem gören 11 otomotiv firmasının adı, ticaret unvanı ve kısaltmaları Tablo 6'da verilmiştir (KAP, 2019). 
Tablo 6: Firmaların Adları, Ticaret Unvanları ve Kısaltmaları

\begin{tabular}{|c|l|c|}
\hline No & Firmaların Adları ve Ticaret Unvanları & Kısaltma \\
\hline 1 & Anadolu Isuzu Otomotiv Sanayi ve Ticaret A.Ş. & Anadolu \\
\hline 2 & Bosch Fren Sistemleri Sanayi Ticaret A.Ş. & Bosch \\
\hline 3 & DiTAŞ Doğan Yedek Parça İmalat ve Teknik A.Ş. & Ditaş \\
\hline 4 & Ege Endüstri ve Ticaret A.Ş & Ege \\
\hline 5 & Federal-Mogul İzmit Piston ve Pim Üretim Tesisleri A.Ş. & Federal- Mogul \\
\hline 6 & Ford Otomotiv Sanayi A.Ş. & Ford \\
\hline 7 & Karsan Otomotiv Sanayi ve Ticaret A.Ş. & Karsan \\
\hline 8 & Katmerciler Araç Üstü Ekipman Sanayi ve Ticaret A.Ş. & Katmerciler \\
\hline 9 & Otokar Otomotiv ve Savunma Sanayi A.Ş. & Otokar \\
\hline 10 & Persan Makine Parçaları Sanayi A.Ş. & Persan \\
\hline 11 & Tofaş Türk Otomobil Fabrikası A.Ş. & Tofaş \\
\hline
\end{tabular}

Ülkemizde otomotiv endüstrisinde faaliyet gösteren birçok firma vardır. Ancak halka açık olmayan firmaların verilerine ulaşılamadığından borsada işlem gören 11 firmanın verileri kullanılarak finansal performans analizi yapılmıştır.

\subsection{Yöntem}

Wang ve Lee (2008), firmanın finansal performansını değerlendirmek için faktör analizi diskriminant analizi, kümeleme analizi gibi birçok yöntemin kullanıldığını ifade etmiş; uygulamada faktör analizi yaparak en çok kullanılan oranları faktör yüklerini göre sınıflandırmış ve kümeleme analizi yapmıştır. Literatürde yapılan çalışmalar incelendiğinde firmaların finansal performans değerlemesinde oran analizinin sıkça kullanıldığı tespit edilmiştir. Ulusal literatürde yapılmış çalışmalar incelendiğinde çeşitli analiz yöntemleriyle firmaların performansları ve/veya etkinlik durumlarının analizi yapıldığı görülmüştür. Bu çalışmada finansal performansa etki eden faktörlerin tespiti ve performans üzerindeki etkisi değerlendirilmiştir. Faktör analizi ve kümeleme analizinin yapıldığı çalışmalardan esinlenerek bu çalışmada açıklayıcı faktör analizi ve kümeleme analizi yapılarak firmaların finansal performanslarına etki eden faktörler tespit edilerek performans sınıflandırmaları yapılmıştır.

Çalışmanın bu bölümünde analizde kullanılan Açıklayıcı Faktör Analizi ve Hiyerarşik Kümeleme Analizi yöntemleri açıklanmaktadır

\subsubsection{Açıklayıcı Faktör Analizi}

Faktör analizi, birbirleriyle ilişkili çok sayıda değişkeni bir araya toplayarak daha az sayıda anlamlı yeni değişkenler (faktörler, boyutlar) keşfetmeyi amaçlayan çok değişkenli istatistiksel bir analiz tekniğidir. Faktör analizinin açıklayıcı (keşfedici) ve doğrulayıcı olmak üzere iki türü bulunmaktadır. Açıklayıcı faktör analizi, değişkenler arası ilişkilerden hareketle faktör bulmaya ve teori geliştirmeye yönelik bir işlem iken, doğrulayıcı faktör analizi ise değişkenler arası ilişkilere dair önceden belirlenen bir modelin ya da hipotezin test edilmesine yönelik bir işlemdir (Büyüköztürk, 2002: 472). Böylece faktör analizi ile birden fazla değişken birkaç başlık altında toplanarak bir "faktör yükü" elde edilebilmektedir (Çetin, 2007: 59). Faktör yükü aynı zamanda açıklama katsayısı olarak ifade edilmektedir. Çalışmada otomotiv firmalarının finansal durumlarını belirleyen oranların faktörlere bölünmesi düşünüldüğünden açıklayıcı faktör analizi uygulanması uygun görülmüş ve elde edilen veriler SPSS 21.0 programında faktör analizine tabi tutularak finansal oran grupları belirlenmiştir.

\subsubsection{Hiyerarşik Kümeleme Analizi}

Kümeleme analizi, grup sayısını belli olmayan ve gruplandırılmamış verilerin benzerliklerine göre sınıflandırılmasında kullanılan çok değişkenli istatistiksel bir analiz tekniğidir. Kümeleme analizi, iki değişkenin benzerlik (yakınlık) ya da uzaklık ölçüsüne bakılarak yapılmaktadır (Çakmak vd., 2005: 17). Kümeleme analizinin hiyerarşik kümeleme ve hiyerarşik olmayan kümeleme olmak üzere iki türü bulunmaktadır. Hiyerarşik kümeleme yönteminde kaç tane küme olacağ 1 bilinmemekte ve " $n$ " birey "k" tane kümeyi göstermektedir. En yakın iki küme birleştirilmekte ve küme sayısı bire indirgenerek yinelenmiş uzaklıklar matrisi bulunmaktadır. Bu işlem $\mathrm{n}-1 \mathrm{kez}$ tekrarlanmaktadır. Dendogram adı verilen ağaç diyagramları analiz sonuçları gösterilmektedir. Hiyerarşik olmayan kümeleme yönteminde ise birimlerin 
uygun oldukları kümelerde toplanmaları ve "n” birimin " $\mathrm{k}$ ” sayıda kümeye parçalanması hedeflenmekte ve küme sayısına önceden karar verilmektedir (Ada Altun, 2011: 321-322). En yaygın kullanılan kümeleme yöntemi hiyerarşik kümeleme yöntemidir. Hiyerarşik kümeleme analizi yöntemi kullanılarak benzer özelliğe sahip nesnelerin ya da olayların gruplandırılarak incelenmesi mümkündür (Koç, 2001: 19-21). Bu nedenle çalışmada otomotiv firmalarına ait veriler hiyerarşik kümeleme yönteminde kullanılarak otomotiv firmalarının finansal performansları açısından sınıflandırılmıştır.

\section{BULGULAR}

Çalışmanın bu bölümünde Faktör Analizi ve Hiyerarşik Kümeleme Analizi ile ilgili bulgulara yer verilmektedir.

\subsection{Faktör Analizi Bulguları}

Otomotiv firmalarının finansal tablo verilerinden elde edilen oranlar SPSS 21,0 programında Aç1klayıcı Faktör Analizine (AFA) tabi tutulmuştur. AFA ile ilgili bulgular Tablo 7 ve Tablo 8 de verilmiştir.

Tablo 7: Finansal Oran Grupları İçin Hesaplanmış Varyans Açıklama Yüzdeleri ve

Faktör Sayıları

\begin{tabular}{|l|c|c|c|}
\hline Oran Grupları & Değişken Sayısı & Faktör Sayısı & Varyans Açıklama Yüzdesi \\
\hline Faaliyet Devir Hızları (F1) & 4 & 1 & 55,346 \\
\hline Kârlıık Oranları (F2) & 5 & 1 & 74,376 \\
\hline Likidite Oranları (F3) & 3 & 1 & 97,856 \\
\hline Mali Yapı Oranları (F4) & 2 & 1 & 91,975 \\
\hline
\end{tabular}

Finansal oran gruplarının açıklama yüzdeleri incelendiğinde "likidite oranları" grubunun en yüksek $(97,856)$ açıklama yüzdesine sahip olduğu görülmektedir. Bu durum likiditenin firmalar için önemli bir faktör olduğunu ortaya koymaktadır. Zira kârlı görünen bir işletme nakit sıkıntısı çekebilirken, kârlı görünmeyen bir firma nakit sıkıntısı çekmeyebilir.

Tablo 8: Finansal Oran Gruplarının Faktör Yükü Matrisi

\begin{tabular}{|c|c|c|c|c|}
\hline & \multicolumn{4}{|c|}{ Bileşenler-Oran Grupları } \\
\hline Oran Adı & $\begin{array}{l}\text { Faaliyet } \\
\text { Devir } \\
\text { Hızları } \\
\text { (F1) }\end{array}$ & $\begin{array}{c}\text { Kârlılık } \\
\text { Oranları } \\
\text { (F1) }\end{array}$ & $\begin{array}{c}\text { Likidite } \\
\text { Oranları } \\
\text { (F3) }\end{array}$ & $\begin{array}{l}\text { Mali Yapı } \\
\text { Oranları } \\
(F 4)\end{array}$ \\
\hline Çalışma Sermayesi Devir Hızı & 0,886 & & & \\
\hline Alacak Devir Hızı & 0,747 & & & \\
\hline Stok Devir Hızı & 0,399 & & & \\
\hline Aktif Devir Hızı & 0,844 & & & \\
\hline Brüt Kâr Marjı & & 0,691 & & \\
\hline Esas Faaliyet Kârlılık Oranı & & 0,908 & & \\
\hline Aktif Kârlılık Oranı & & 0,916 & & \\
\hline Özsermaye Kârlılık Oranı & & 0,810 & & \\
\hline Net Kâr Marjı & & 0,959 & & \\
\hline Cari Oran & & & 0,991 & \\
\hline Asit Test Oranı & & & 0,996 & \\
\hline Nakit Oran & & & 0,981 & \\
\hline Toplam Borç/Toplam Pasif Oranı & & & & 0,959 \\
\hline Kısa Vadeli Yabancı Kaynaklar/Toplam Pasif Oranı & & & & 0,959 \\
\hline
\end{tabular}


AFA sonucunda oranlar literatüre uygun bir şekilde dört faktör altında toplanmıştır:

1.Faktör: Faaliyet Devir Hızları (Çalışma Sermayesi Devir Hızı, Alacak Devir Hızı, Stok Devir Hızı, Aktif Devir Hızı),

2.Faktör: Kârlılık Oranları (Brüt Kâr Marjı, Esas Faaliyet Kârlılık Oranı, Aktif Kârlılık, Öz sermaye Kârlılık, Net Kâr Marji),

3.Faktör: Likidite Oranlanı (Cari Oran, Asit Test Oranı, Nakit Oran),

4.Faktör: Mali Yapı Oranlarından (Toplam Borç/Toplam Pasif, Kısa Vadeli Yabancı Kaynaklar/Toplam Pasif Oranı) oluşmaktadır.

Faaliyet Devir Hızları oran grubunu en çok Çalışma Sermayesi Devir Hızı $(0,886)$, Kârlılık Oranları grubunu en çok Net Kâr Marjı $(0,959)$, Likidite Oranları grubunu en çok Cari Oran $(0,991)$ açıklamaktadır. Çalışma sermayesi devir hızı firmanın günlük hayatta en çok işlem yaptığı varlılarından biridir. Faaliyet devir hızı oran grubunda söz konusu oranının belirleyici bir role sahip olması nakit, alacak ve stokların etkin kullanılma durumunun tespiti için önemlidir. Mali Yapı Oranları grubunu ise Toplam Borç/Toplam Pasif $(0,959)$ ve Kısa Vadeli Yabancı Kaynaklar/Toplam Pasif $(0,959)$ eşit düzeyde açıklamaktadır. Firmaların mali yapılarını açıklayacak birçok oran vardır. Toplam pasif içindeki kısa vadeli borçların oranı, borçların yüzde kaçının kısa vadeli olduğunu göstermektedir. Oran çalışma sermayesi ile birlikte değerlendirildiğinde firma için önemli bilgiler vermektedir. Ayrıca toplam borcun toplam pasif içindeki oranı, firmanın sermayesinin yabancı ve özkaynaklar dağılımını göstermektedir. "Alacakların Ortalama Tahsil Süresi, Stok Devir Süresi ve Devamlı Sermaye/Maddi Duran Varlıklar" oranlarının faktör yükleri çok düşük çıktığı için analiz dışı bırakılmıştır. Alacakların ortalama tahsil süresi ve stok devir süresi oranları firmaların alacak ve stok yönetimi politikalarının belirlenmesinde önemli bir gösterge olarak kullanılmaktadır. Ancak yukarıda ifade edilen "Alacakların Ortalama Tahsil Süresi ve Stok Devir Süresi” oranlarının analiz sonuçlarında anlamlı çıkmayışı, alacak devir hızı ve stok devir hızı oranlarının analizde kullanılmış olmasından kaynaklanabileceği düşünülmektedir.

AFA sonucunda elde edilen her bir finansal orana ait faktör yükleri ile otomotiv firmalarına ait finansal oran değerleri çarpılarak bir hesaplama yapılmıştır (Firmaların finansal oran değerleri X faktör yükleri). Bu hesaplama sonucunda elde edilen değerler Tablo 9` da verilmiştir.

Tablo 9: Firmaların Faktör Matrisleri (Rasyolar X Faktör Yükleri)

\begin{tabular}{|l|c|c|c|c|c|c|c|c|}
\hline \multicolumn{1}{|c|}{ Yillar } & $\mathbf{2 0 1 0}$ & $\mathbf{2 0 1 1}$ & $\mathbf{2 0 1 2}$ & $\mathbf{2 0 1 3}$ & $\mathbf{2 0 1 4}$ & $\mathbf{2 0 1 5}$ & $\mathbf{2 0 1 6}$ & $\mathbf{2 0 1 7}$ \\
\hline Anadmalar & & & & & & & & \\
\hline Bosch & 9,283523 & 10,96488 & 10,4963 & 12,61668 & 10,36332 & 15,08356 & 9,374618 & 8,171084 \\
\hline Ditaş & 10,32131 & 12,61984 & 19,07383 & 22,82029 & 16,80331 & 22,21936 & 23,05524 & 21,43978 \\
\hline Ege & 10,95114 & 13,73863 & 28,66014 & 20,81089 & 14,90547 & 13,14173 & 11,35609 & 11,7027 \\
\hline Federal-Mogul & 9,052411 & 11,31845 & 14,43893 & 15,32738 & 20,59091 & 24,10642 & 26,90234 & 25,06025 \\
\hline Ford & 47,22651 & 58,14676 & 48,25278 & 51,92373 & 31,46635 & 44,05999 & 34,86362 & 37,71882 \\
\hline Karsan & 21,72305 & 21,44932 & 21,18148 & 24,65039 & 21,93927 & 22,67891 & 22,16973 & 23,59621 \\
\hline Katmerciler & 17,6493 & 21,62317 & 50,39575 & 32,84007 & 7,365311 & 10,68371 & 8,975697 & 10,94791 \\
\hline Otokar & 12,09462 & 7,843686 & 21,12718 & 12,01949 & 8,525734 & 12,44011 & 6,91035 & 6,740329 \\
\hline Persan & 10,60242 & 11,11225 & 11,42922 & 11,28457 & 11,38139 & 10,46816 & 10,48269 & 11,30297 \\
\hline Tofaş & 11,82396 & 12,65011 & 13,64743 & 10,70518 & 12,51947 & 10,79217 & 11,21679 & 9,575159 \\
\hline
\end{tabular}

Tablo 9'da verilen değerler her bir firmanın her yıl için hesaplanan oranların faktör yükleri ile çarpılması ve elde edilen tutarların toplanmasıyla hesaplanmıştır. Örneğin Tofaş firmasının 2017 yılı oranları teker teker ilgili faktör yükleri ile çarpılmış ve toplanarak Tofaş firmasının 2017 yılına ait faktör matrisi oluşturulmuştur. Böylece 14 oranının firmanın performansı üzerinde etkisi tek bir sayısal değer ile ifade edilmiştir. Oranların her birinin ayrı ayrı değerlendirilmesi finansal performans üzerinde ortak bir değerlendirme yapma imkânı vermediğinden, faktör matrislerinin hesaplanmasıyla finansal performansların karşılaştırılması mümkün olmuştur. 


\subsection{Kümeleme Analizi Bulguları}

Faktör matris değerleri SPSS 21.0 programında hiyerarşik kümeleme analizine tabi tutularak firmalar finansal performanslarına göre sınıflandırılmıştır. Hiyerarşik kümeleme analizinde iki küme oluşmuş ve Tablo $10 `$ da analize ilişkin Aglomeratif Çizelge verilmiştir.

Tablo 10: Aglomeratif Çizelge

\begin{tabular}{|c|c|c|c|}
\hline Basamak (Sıra) & Küme 1 & Küme 2 & Coefficients (Katsayı) \\
\hline 1 & Otokar & Persan & 7,019 \\
\hline 2 & Ford & Tofaş & 15,210 \\
\hline 3 & Anadolu & Otokar & 42,567 \\
\hline 4 & Bosch & Ege & 105,939 \\
\hline 5 & Anadolu & Katmerciler & 204,525 \\
\hline 6 & Anadolu & Ditaş & 470,813 \\
\hline 7 & Bosch & Ford & 749,884 \\
\hline 8 & Anadolu & Karsan & 2133,575 \\
\hline 9 & Anadolu & Bosch & 3599,797 \\
\hline 10 & Anadolu & Federal-Mogul & 9837,525 \\
\hline
\end{tabular}

Aglomeratif çizelgede katsayıya (Coefficients) göre birbirlerine finansal açıdan en çok benzeyen firmalar eşleşmiştir. Buna göre birbirine en çok benzeyen firmalar 1.basamakta Otokar ve Persan $(7,019)$ iken, birbirine en az benzeyen 10.basamakta yer alan Anadolu ve Federal-Mogul $(9837,525)$ firmalarıdır. Otokar ve Persan firmalarının aktif büyüklükleri birbirlerine yakındır. Ancak satış gelirleri açısından değerlendirildiğinde Otokar, Persan'dan neredeyse 5 kat daha fazla satış yapmaktadır. İki firmanın birbirine yakın performans sergilemeleri düşündürücüdür. Ford ve Tofaş firmaları otomotiv sektöründeki firmaların toplam aktiflerinin \%77'lik kısmını oluşturmaktadır. Satış gelirleri açısından da iki firmanın verileri birbirine oldukça yakındır. Hiyerarşik kümeleme analizinde iki firmanın finansal performansının birbirine yakın olması endüstrideki mevcut durum ile analiz sonuçlarının örtüştüğünü göstermektedir. Analiz sonuçlarında 10.basamakta yer alan Anadolu ve Federal-Mogul firmalarının finansal performanslarının birbirleriyle uzak olduğunu göstermektedir. Firmaların büyüklük, satış gelirleri, kârlılıkları, çalışan sayıları karşılaştırıldığında iki firmanın birbiriyle mukayese edilemeyecek kadar farklı olduğu görülmektedir.

Hiyerarşik Kümeleme Analizi sonuçlarını göstermede kullanılan Dendogram (ağaç diyagramı) yöntemi incelendiğinde ise finansal durum bakımından birbirlerine en çok benzeyen firmalar 1 birimlik mesafede grup oluştururken, birbirlerine en az benzeyen firmalar 25 birimlik mesafede bir araya gelmektedir. Ağaç diyagram1 Şekil 1 `de gösterilmektedir.

Şekil 1: Ağaç Diyagramı (Dendogram)

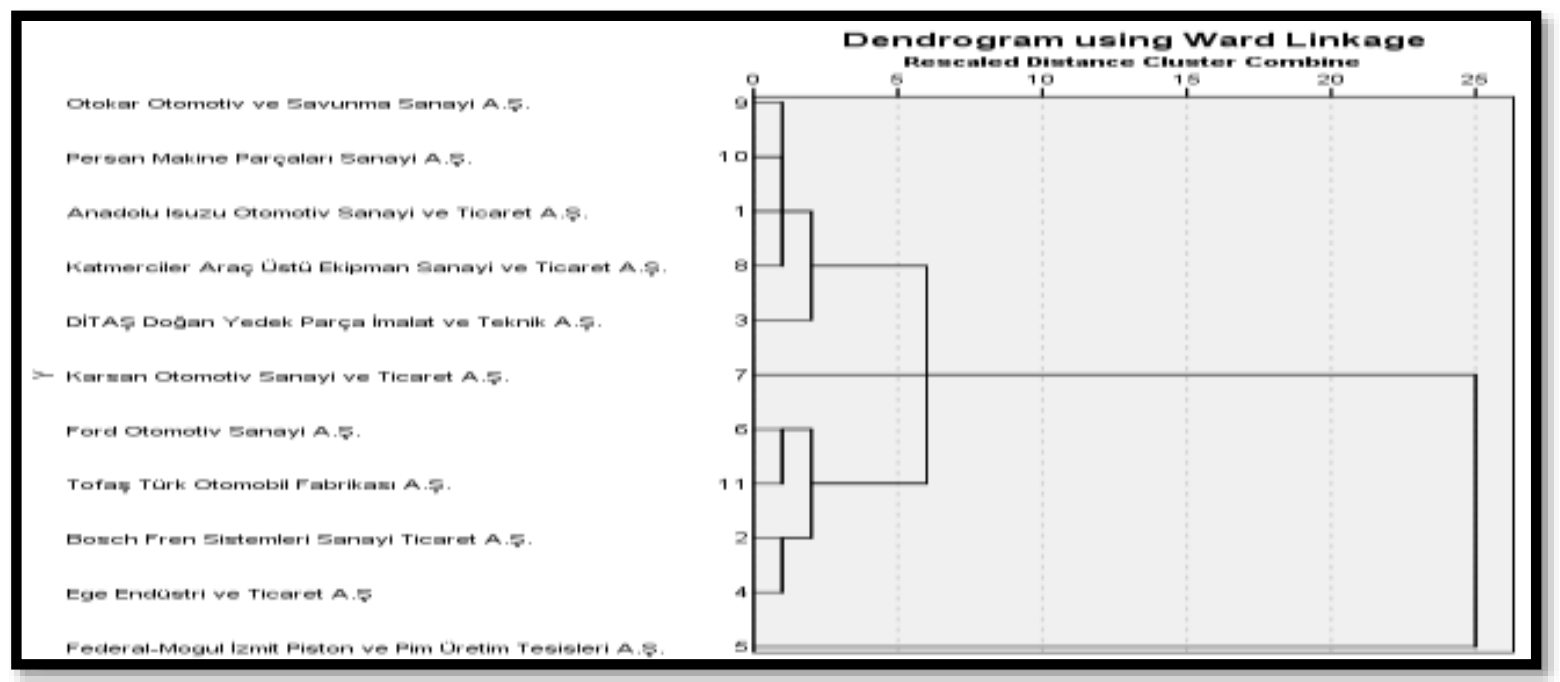


Ağaç diyagramına göre 1 birimlik mesafede 4 grup, 2 birimlik mesafede 2 grup, 6 birimlik mesafede ve 25 birimlik mesafede 1 grup oluşmaktadır. İlk bakışta Otokar-Persan, Anadolu-Katmerciler, Ford-Tofaş, BoschEge bir birimlik mesafede grup oluşturduğu görülmektedir. Anadolu-Ditaş, Ford-Bosch firmaları iki birimlik, Katmerciler ve Tofaş altı birimlik ve Karsan-Federal Mogul firmaları ise 25 birimlik mesafede grup oluşturdukları görülmektedir. Otokar ile Persan, Katmerciler-Anadolu firmalarının finansal performansları karşılaştırıldığında, bazı firmaların likidite ve mali yapı rasyoları; bazılarının da kârlılık ve faaliyet oranlarının diğerinden iyi olduğu dolayısıyla birbirlerine benzer performans sergiledikleri görülmektedir. Katmerciler ve Tofaş firmalarının oran analizi sonuçları incelendiğinde, Tofaş firmasının Katmerciler'den yüksek performans sergilemesi, aralarındaki mesafenin fazla oluşu oranların değerlerindeki farklılıklardan kaynaklanabileceği düşünülmektedir. Karsan ve Federal-Mogul aralarındaki mesafe diğer firmalardan oldukça fazladır. Oranlar incelendiğinde iki firmanın değerlerinin birbirlerinden epeyce farklılık gösterdiği görülmektedir.

\section{SONUÇ VE TARTIŞMA}

Otomotiv sektörü dünya ekonomisinde önemli bir paya sahiptir. Türkiye ekonomisi içinde aynı durum söz konusudur. Bu nedenle performansları her geçen yıl artan firmaların finansal performanslarını incelemek ve karşılaştırmak amacıyla bu çalışma yapılmıştır. Otomotiv sektöründe faaliyet gösteren çok sayıda firma olmasına rağmen, finansal tablolara ulaşılamadığından, uygulama Borsa İstanbul'da işlem gören firmalar üzerinde yapılmıştır. Uygulama kapsamındaki firmalar ülkemiz otomotiv sektöründeki en büyük firmalar olduğundan çalışmanın sonuçlarının ana kütleyi yansıtma gücü oldukça yüksektir. Finansal performans değerlemesi firmaların yönetim kararları üzerinde önemli bir etkiye sahiptir. Bu nedenle stratejik yönetim sürecinde firmaların finansal performanslarının incelenmesi, performansa etki eden faktörlerin tespit edilmesi ve karşılaştırılması, firmaların finansal durum ve performanslarının rakipleriyle kıyaslanması firmaların sektördeki uzun dönemde başarılarının devamı için son derece önemlidir.

Uygulama da literatürde sıkça kullanılan oran analizi yapılmıştır. Önceki çalışmalarda olduğu üzere literatürde en çok kullanılan oranlar analizde tercih edilmiştir. Çalışmanın ilk kısmında oran analizindeki çeşitli oranlar hesaplanarak faktör analizi yapılmıştır. Çalışma sermayesi devir hızı, alacak devir hızı, stok devir hızı, aktif devir hızı bir grupta; brüt kâr marjı, esas faaliyet kârlılık oranı, aktif kârlılık oranı özsermaye kârlılık oranı ve net kâr marjıda bir grupta; cari oran, asit test oranı ve nakit oran bir grupta ve toplam borç/toplam pasif, KVYK/Toplam pasif oranı da bir grupta toplanmıştır. Dolayısıyla faktör analizi sonucuna göre oranlar olması gereken gruplarda toplanmıştır. Firmaların finansal performanslarının değerlendirilmesinde çalışma sermayesi devir hızının önemli bir etkiye sahip olduğu tespit edilmiştir. Faaliyet oranları içinde çalışma sermayesi devir hızı firmanın dönen varlıklarının etkin kullanma durumunu göstermektedir. İşletmelerin faaliyetlerini sürdürebilmelerinde çalışma sermayesinin etkin yönetilmesi önem arz etmektedir. Çalışma sermayesi yönetiminde likidite önemlidir. Likidite durumunun değerlendirilmesinde en anlamlı sonucu veren cari orandır. Cari oran, likidite düzeyinin ölçülmesinde kullanılan temel bir göstergedir. Cari oran firmaların dönen varlıklar ile kısa vadeli yabancı kaynaklar arasındaki dengenin değerlendirilmesinde kullanılabilmektedir. Literatürde yapılmış çalışmalar incelendiğinde, likidite durumunu değerlendirilmesinde cari oran ile asit test oranının belirleyici olduğu tespit edilmiştir. Analiz sonuçlarına göre kârlılık oranları grubunda net kâr marjı öne çıkmış olup firmaların nihai başarılarının tespitinde en çok kullanılan orandır. Literatürde finansal performans değerlemesinde kârlılık oranlarının önemli bir ölçüt olduğu ifade edilmiş olup bazı çalışmalarda ise özsermaye kârlılık oranının önemli bir gösterge olduğu tespit edilmiştir. Çalışmanın faktör analizi sonuçları, önceki çalışmalarda ile bağdaşmaktadır.

Firmaların finansal performanslarına etki eden oranlar faktör analizi ile tespit edildikten sonra faktör yüklerine göre kümeleme analizi yöntemi ile sınıflandırılmıştır. Böylece aktif büyüklükleri veya satış gelirleri farklı olan 11 firmanın performanslarına göre kümelere ayrılmıştır. Kümeleme analizinde Otokar-Persan, Anadolu-Katmerciler, Ford-Tofaş, Bosch-Ege firmalarının birbirlerine benzer performans gösterdikleri görülmektedir. Anadolu-Ditaş, Ford-Bosch firmalarının performanslarının benzer olduğu tespit edilmiştir. Karsan-Federal Mogul firmalarının kümeleme analizinde en uzak mesafede yer almaları, performanslarının farklılığını göstermektedir. Otokar ile Persan, Katmerciler-Anadolu firmalarının finansal performansları karşılaştırıldığında, bazı firmaların likidite ve mali yapı oranları; bazılarının da kârlılık ve faaliyet oranlarının diğerinden iyi olduğu dolayısıyla birbirlerine benzer performans sergiledikleri görülmektedir. Tofaş firmasının Katmerciler'den yüksek performans sergilemesi, aralarındaki mesafenin fazla oluşu oranların değerlerindeki farklılıklardan kaynaklanabileceği düşünülmektedir. Oran analizinde firmaların ölçekleri önem arz etmektedir. Büyük bir firmanın özkaynakları veya toplam aktifi, küçük firmalarınkinden büyük olacağından, oran analizinde değerlerin küçük çıkmasına neden olabilmektedir. Aktif büyüklükleri farklı firmaların aynı analize tabi tutulması, analiz sonuçlarını olumsuz yönde etkileyebilmektedir. $\mathrm{Bu}$ durum önceki çalışmaların 
sonuçlarıyla örtüşmektedir. Literatürde yapılacak çalışmalarda firmaların finansal performanslarının tespitinden daha çok finansal risk düzeylerinin incelenmesi tavsiye edilmektedir. Döviz kurundaki değişimin firmaların yatırımlarına ve sermaye maliyeti üzerine etkisi incelenebilir. Analizin uzun bir dönemde yapılması, ülkenin makroekonomik gelişimiyle ilişkilendirilmesi ve kriz dönemlerindeki etkinin tespit edilmesinin literatüre önemli katkılar sağlayacağı düşünülmektedir. 


\section{KAYNAKÇA}

Ada Altun, A. (2011) "Kümeleme Analizi ile AB Ülkeleri ve Türkiye’nin Sürdürülebilir Kalkınma Açısından Değerlendirilmesi", Dumlupınar Üniversitesi Sosyal Bilimler Dergisi, (29), 319-332.

Afzal, F., Afzal, F., Khan, S. M., ve Sajid, M. (2013) "Impact of Global Financial Crisis 2008 on Automobile Industry", Research Journal of Finance and Accounting, 4(2), 136-145.

Akdoğan, N. ve Tenker, N. (2007) Finansal Tablolar ve Mali Analiz Teknikleri, Ankara, Gazi Kitabevi.

Anadolu Isuzu (2018). https://www.anadoluisuzu.com.tr/yatirimci-iliskileri/finansal-raporlar, Erişim Tarihi: 01.08.2018.

Arumugam, D., M., A. K. ve R., P. (2016) "Factors Determining Profitability in Indian Automobile Industry", Indian Journal of Commerce \& Management Studies, VII(2), 64-69.

Bakırcı, F. (2006) "Sektörel Bazda Bir Etkinlik Ölçümü: VZA ile Bir Analiz", Atatürk Üniversitesi İktisadi ve İdari Bilimler Dergisi, 20(2), 199-217.

Bayraktar, B. (2004) "Otomobil Sektöründe Uygulanan Önemli Demografik Bölümlendirme Kriterleri (Genel Bir Bakış)", Balıkesir Üniversitesi Sosyal Bilimler Enstitüsü Dergisi, 7(11), 1-10.

Bosch (2018). http://www.boschfren.com.tr/tr/tr/bosch_fren_sistemleri/investor_relations/chassissystems_2.html, Erişim Tarihi: 01.08.2018.

Bulgurcu, B. (2013) "Financial Performance Ranking of the Automotive Industry Firms in Turkey: Evidence from an Entropy-Weighted Technique", International Journal of Economics and Financial Issues, 3(4), 844-851.

Büyüköztürk, Ş. (2002) "Faktör Analizi: Temel Kavramlar ve Ölçek Geliştirmede Kullanımı", Kuram ve Uygulamada Eğitim Yönetimi, (32), 470-483.

Chen, K. H. ve Shimerda, T. A. (1981) "An Empirical Analysis of Useful Financial Ratios", Financial Management, $10(1), 51-60$.

Cop, R. ve Gümüş, N. (2009) "Pazarlamada Ağızdan Ağza İletişimin Tüketici Davranışlarındaki Rolü ve Bir Araştırma", Ticaret ve Turizm Eğitim Fakültesi Dergisi, (2), 179-202.

Çabuk, A. ve Lazol, İ. (2016) Mali Tablolar Analizi, Ekin Basım Yayın Dağıtım, Bursa.

Çakmak, Z., Uzgören, N. ve Keçek, G. (2005) "Kümeleme Analizi Teknikleri ile İllerin Kültürel Yapılarına Göre Sınıflandırılması ve Değişimlerinin İncelenmesi", Dumlupınar Üniversitesi Sosyal Bilimler Dergisi, (12), 15-36.

Çetin, A. C. (2007) "Şirket Derecelendirilmesinde Faktör Analizi Kullanımı ve Sektörlere Yönelik Bir Uygulama", Süleyman Demirel Üniversitesi İktisadi ve İdari Bilimler Fakültesi Dergisi, 12(3), 53-74.

Dayı, F. (2013) Sağlık İşletmelerinde Uygulamalı Finansal Analiz, Ekin Basım Yayın Dağııım, Bursa.

Dharmaraj, A. ve N. Kathirvel. (2012) "Financial Performance of Indian Automobile Industry - A Comparative Study During Pre and Post Foreign Direct Investment", International Journal of Scientific Research, 2(9), 54-56.

Ditaş Doğan (2018) http://www.ditas.com.tr/yatirimci-iliskileri-raporlar-ve-sunumlar, Erişim Tarihi: 01.08.2018.

Ege, İ., Topaloğlu, E. E. ve Özyamanoğlu, M. (2013) "Finansal Performans ile Kurumsal Yönetim Notları Arasındaki İlişki: BIST Üzerine Bir Uygulama", Akademik Araştırmalar ve Çalışmalar Dergisi, 5(9), 100-117.

Ege Endüstri http://egeendustri.com.tr/indexx.php?f=ed0639f36c56566325bc73162c9f961b\&l=1\&sayfa_id=102\&g_id=\&id= 1123, Erişim Tarihi: 01.08 .2018$.

Falát, L. ve Holubčík, M. (2017) "The Influence of Marketing Communication on Financial Situation of the Company-A Case from Automobile Industry", Procedia Engineering, 192, 148-153.

Federal Mogut (2018). http://www.fmizp.com/Yonetim/FinansalRaporlar.aspx, Erişim Tarihi: 01.08.2018

Ford (2018). https://www.fordotosan.com.tr/tr/yatirimcilar/finansal-raporlar/finansal-raporlar, Erişim Tarihi: 01.08.2018.

Gonenc, H. ve Scholtens, B. (2017) "Environmental and Financial Performance of Fossil Fuel Firms: A Closer Inspection of their Interaction", Ecological Economics, 132, 307-328.

Gowda, P. R. ve V., M. K. (2017) "Financial Performance Analysis as A determinant of Profitability in Indian automobile industry", BRDU International Journal of Multidisciplinary Research, 2(III), 64-75.

Helfat, C. E. ve Raubitschek, R. S. (2000) "Product Sequencing: Co-Evolution Of Knowledge, Capabilities And Products", Strategic Management Journal, 21, 961-979.

Ildırar, M. ve Kıral, E. (2018) "Piyasa Yapısı ve Yoğunlaşma: Türk Otomotiv Sektörü Üzerine Bir Analiz", AİBÜ Sosyal Bilimler Enstitüsü Dergisi, 18(1), 93-117.

Jothi, K. ve Geethalakshmi, A. (2016) "Liquidity and Profitability Position of Select Automobile Companies in India", International Journal of Advance Research in Computer Science and Management Studies, 4(1), 262-268.

Jothi, K. ve Kalaivani, P. (2015) "A Study on Financial Performance of Honda and Toyota Automobile Company a Comparative Analysis", Journal of Progressive Research in Social Sciences, 2(1), 33-35.

KAP. (2018). https://www.karsan.com.tr/tr/yatirimci-iliskileri/finansal-bilgiler/faaliyet-raporlari, Erişim Tarihi: 01.08.2018.

Katmerciler (2018). https://www.kap.org.tr/tr/Sektorler, Erişim Tarihi: 01.08.2018.

Karsan (2018). https://www.karsan.com.tr/tr/yatirimci-iliskileri/finansal-bilgiler/faaliyet-raporlari, Erişim Tarihi: 01.08.2018.

KPMG (2018) Otomotiv Sektörel Bakış. http://www.osd.org.tr/sites/1/upload/files/sektorel-bakis-2018-otomotiv4314.pdf, Erişim Tarihi: 10.10.2018. 
Koç, S. (2001) "Türkiye`de İllerin Sosyo-Ekonomik Özelliklere Göre Sınıflandırılması", V.Ulusal Ekonometri ve İstatistik Sempozyumu. Adana.

Kushwaha, G. S. ve Sharma, N. K. (2016) "Green initiatives: A Step Towards Sustainable Development and Firm's Performance in the Automobile Industry", Journal of Cleaner Production, 121, 116-129.

Küçüközkan, Y. (2017) Hastanelerde Finansal Performans Yönetimi. $09 \quad 27, \quad 2018$ tarihinde https://www.saglikaktuel.com/yazi/hastanelerde-finansal-performans-yonetimi-7068.htm, Erişim Tarihi: 27.09.2018.

Lepak, D. P. ve Snell, S. A. (1999) "The Human Resource Architecture: Toward a Theory of Human Capital Allocation and Development", The Academy of Management Review, 24(1), 31-48.

Lev, B. ve Sunder, S. (1979) "Methodological Issues in The Use of Financial Ratios", Journal of Accounting and Economics, 1(3), 187-210.

Mathur, S. ve Agarwal, K. (2016) "Financial Analysis Of Automobile Industries (A Comparative Study Of Tata Motors And Maruti Suzuki)", International Journal of Applied Research, 2(9), 533-539.

Mesarić, M. (2014) "Ratio Analysis and Piotroski Scoring System in the Automobile Industry in Crotia", Ekonomski Vjesnik/ Econviews, XXVII(1), 127-141.

Morgan, N. A. (2012) "Marketing and Business Performance", Journal of the Academy of Marketing Science, 40(1), 102119.

ODD. (2018) Avrupa Otomotiv Pazarı 2018 Yılı Haziran Ayı Sonunda \%3,0 Arttı, Otomotiv Distribütörleri Derneği. http://www.odd.org.tr/folders/2837/categorial1docs/2220/BASIN\%20B\%C3\%9CLTEN\%C4\%B0\%2026\%20TE MMUZ\%202018.pdf

Okka, O. (2015) Finansal Yönetim Teori ve Çözümlü Problemler, Nobel Akademik Yayıncılık, Ankara.

Otokar (2018). https://www.otokar.com.tr/tr/yatirimci-iliskileri, Erişim Tarihi: 01.08.2018.

Ömürbek, N., Karaatlı, M. ve Balcı, H. F. (2016) "Entropi Temelli MAUT ve SAW Yöntemleri İle Otomotiv Firmalarının Performans Değerlemesi", Dokuz Eylül Üniversitesi İktisadi ve İdari Bilimler Fakültesi Dergisi, 31(1), $227-255$.

Özşahin, M. ve Yüregir, O. H. (2012) "Otomotiv Sektörünün Kendini Örgütleyen Haritalar ile Finansal Analizi", Ç.Ü Fen ve Mühendislik Bilimleri Dergisi, 28(2), 155-164.

Pal, S. (2015) "Evaluation of Financial Performance in Terms of Financial Ratios- An Emprical Study on Indian Automobile Industry", International Journal of Business Management \& Research, 5(3), 1-7.

Persan (2018). http://www.parsan.com/index.php/mali-tablo-ve-raporlar/, Erişim Tarihi: 01.08.2018.

Polonsky, M. J. ve Rosenberger, P. J. (2001) "Reevaluating Green Marketing: A Strategic Approach", Business Horizons, 44(5), 21-30.

Ramya, A. ve S.Kavitha. (2017) "A Study on Financial Analysis of Maruthi Suzuki India Limited Company", Journal of Business and Management, 19(7), 93-101.

SAP Business Objects. (2009) Finansal Performans Yönetimi., SAP AG. http://www.acron.com.tr/wpcontent/uploads/2012/09/FinancialPerformanceManagement.pdf, Erişim Tarihi: 26.09.2018.

Srivastava, R. K., Shervani, T. A. ve Fahey, L. (1999) "Marketing, Business Processes, and Shareholder Value: An Organizationally Embedded View of Marketing Activities and the Discipline of Marketing", Journal of Marketing, $63,168-179$.

Szucs, G. (2015) "The Financial Analysis of The Hungarian Automotive Industry Based on Profitability and Capital Structure Ratios", Central European Business Review, 4(1), 61-73.

Tatlı, H. ve Bayrak, R. (2016) "Borsa İstanbul'da Kayıtlı Otomotiv Sektöründe Faaliyet Gösteren Firmaların Etkinliklerinin Statik ve Dinamik Veri Zarflama Analizi Yöntemiyle Değerlendirilmesi", Siyaset, Ekonomi ve Yönetim Araştırmaları Dergisi, 4(1), 119-145.

Teece, D. J., Pisano, G. ve Shuen, A. (1997) "Dynamic Capabilities and Strategic Management", Strategic Management Journal, 18(7), 509-533.

Tofaş (2018). https://tofas.com.tr/YatirimciIliskileri/FinansalSonuclar/Pages/default.aspx, Erişim Tarihi: 01.08.2018.

Ulusoy, T. (2008) "Systematic Risk and Firm Financial Structure: Evidence on Istanbul Stock Exchange", The Business Review, Cambridge, 11(2), 226-231.

Ulusoy, T. (2011) "Financial Power Analysis of Countries: Transmitters (adsorbents), Setters and Unresistants", African Journal of Business Management, 5(22), 9087-9105.

Wang, Y.-J. ve Lee, H.-S. (2008) "A Clustering Method to Identify Representative Financial Ratios", Information Sciences, 178(4), 1087-1097.

Wolters Kluwer/CCH Tagetik. (2018) Financial Performance Management. https://www.tagetik.com/en/glossary/financial-performance-management\#.W6uTCmgzY2x, Erişim Tarihi: 26.09.2018.

Xi, L., Lei, L. ve Guisheng, W. (2009) Evolution of the Chinese Automobile Industry from a Sectoral System of Innovation Perspective. Industry and Innovation, 16(4-5), 463-478.

Yanık, L. ve Eren, T. (2017) Borsa İstanbul'da İşlem Gören Otomotiv İmalat Sektörü Firmalarının Finansal Performanslarının AHP, TOPSIS, ELECTRE ve VIKOR Yöntemleri ile Analizi. Yalova Sosyal Bilimler Dergisi, 8(13), 165-188.

Yurdakul, M. ve İç, Y. T. (2003) Türk Otomotiv Firmalarının Performans Ölçümü ve Analizine Yönelik TOPSIS Yöntemini Kullanan Bir Örnek Çalışma. Gazi Üniv. Müh. Mim. Fak. Der., 18(1), 1-18. 